\title{
Metabolic Dependence of Red Cell Deformability
}

\author{
Robert I. Weed, Paul L. LaCeule, and Edward W. Merrill with the \\ technical assistance of Mrs. Gael Craib, Miss ANN Gregory, \\ Mr. Fred Karch, and Mrs. Frances Pickens \\ From the Departments of Medicine and of Radiation Biology and Biophysics, \\ University of Rochester School of Medicine and Dentistry, Rochester, New \\ York 14620 and the Department of Chemical Engineering, Massachusetts \\ Institute of Technology, Cambridge, Massachusetts 02139
}

A BSTRACT The contribution of the metabolic state of human erythrocytes to maintenance of cellular deformability was studied during and after in vitro incubation in serum for periods up to $28 \mathrm{hr}$. An initial loss of membrane deformability became apparent between 4 and $6 \mathrm{hr}$ when cellular adenosine triphosphate (ATP) levels were approximately $70 \%$ of initial values. Membrane deformability then remained stable between 6 and $10 \mathrm{hr}$.

After $10 \mathrm{hr}$, when cellular ATP had decreased to $<15 \%$ of initial values, progressive parallel changes occurred in red cell calcium which increased $400 \%$ by $24 \mathrm{hr}$ and in the viscosity of red cell suspensions which had risen $500-750 \%$ at $24 \mathrm{hr}$. A further progressive decrease in membrane deformability also occurred and was reflected by a $1000 \%$ increase in negative pressure required to deform the membrane. Red cell filterability decreased to zero as the disc-sphere shape transformation ensued. These changes were accompanied by an increase in ghost residual hemoglobin and nonhemoglobin protein.

Regeneration of ATP in depleted cells by incubation with adenosine produced significant reversal of these changes, even in the presence of ouabain. Introduction of calcium into reconstituted ghosts prepared from fresh red cells mimicked the depleted state, and introduction of ATP, ethylenediamine tetraacetate (EDTA), and magnesium into depleted cells mimicked the adenosine effects in intact depleted cells. ATP added externally to 24-hr depleted cells was without effect. Simultaneous introduction of EDTA, ATP, or magnesium along with calcium into reconstituted ghosts prevented the marked decrease in deformability produced by calcium alone. Incorporation of adenosine diphosphate (ADP), nicotinamide adenine dinucleotide (NAD), NAD phosphate (NADP), NADP, reduced form (NADPH), gluta-

Received for publication 28 March 1968 and in revised form 18 October 1968. tione, reduced form (GSH), inosine triphosphate (ITP), guanosine triphosphate (GTP), and uridine triphosphate (UTP) was without effect.

These data suggest that a major role of ATP in maintenance of red cell viability relates to preservation of red cell membrane deformability. It is proposed that the changes seen in the physical properties of ATPdepleted erythrocytes represent ATP-calcium-dependent sol-gel changes occurring at the interface between the membrane and the cell interior, and that the sol-gel balance determines membrane deformability.

\section{INTRODUCTION}

During the course of previously reported studies on the effects of adenosine triphosphate (ATP) depletion of human erythrocytes on critical hemolytic volume (1), it was noted that ATP-depleted blood manifested a gross increase in viscosity associated with an increase in red cell rigidity which was observable microscopically. These observations suggested that the viscosity of red cell suspensions and red cell deformability were dependent on the metabolic state of the erythrocytes. The present work was undertaken to relate viscosity of red cell suspensions, cellular filterability, and membrane deformability to cellular ATP and calcium levels, as well as investigating the possible importance of cell surface charge and volume to the observed alterations.

Ponder (2) has called attention to many types of chemical and physical treatments which are capable of producing disc-sphere shape tranformations in erythrocytes. Nakao, Nakao, Yamazoe, and Yoshikawa $(3,4)$ have demonstrated that depletion of erythrocyte ATP also produces the disc-sphere transformation and that the latter was reversible upon restoration of ATP levels by incubation with adenine plus inosine. Reed and Swisher have demonstrated that red cells from patients with 
hereditary spherocytosis (HS) (5) which have undergone metabolic depletion in vitro over $24 \mathrm{hr}$ and normal red cells incubated for 36-48 hr (6) manifest significant loss of membrane lipid. Membrane lipid is lost similarly from normal erythrocytes stored in acid citrate dextrose (ACD) solution (7) for more than 21 days. Previous work from this laboratory (1) has demonstrated that incubation of HS cells for $24 \mathrm{hr}$ and normal erythrocytes for $36 \mathrm{hr}$ or more results in a marked decrease in critical hemolytic volume, one of the prime determinants of the osmotic fragility and autohemolysis patterns of incubated cells. The observed decreases in critical hemolytic volume were consistent with decrease in surface area secondary to loss of membrane lipid.

Based on the above observations, it has been suggested previously (1) that the following sequence of events interrelate these various phenomena: ATP depletion is followed by change in shape from disc to crenated sphere, with subsequent fragmentation loss of membrane lipid in crenated buds or myelin forms from the tips of crenations. The loss of lipid produces final transformation of the crenated sphere to a smooth sphere having decreased surface area and critical hemolytic volume. An important but unexplained facet of the observed sequence of events associated with metabolic depletion is the time course of their occurrence and, in particular, the lag between disappearance of ATP and the subsequent decrease in critical volume and loss of lipid. Therefore, the present study was also directed toward characterization of the time course of changes in physical properties of normal erythrocytes in relation to ATP depletion.

The results, including additional data on nonhemoglobin protein and hemoglobin content of ghosts prepared from metabolically depleted erythrocytes, provide support for an hypothesis which suggests that the changes in the physical properties of the red cell occur secondary to an ATP- and calcium-mediated reversible sol-gel transformation occurring at the interface between the cell membrane and the soluble interior of the cell.

\section{METHODS}

Blood was obtained from hematologically normal adult donors, defibrinated, and either studied immediately or incubated at $37^{\circ} \mathrm{C}$ in polypropylene flasks under sterile conditions for varying periods of time up to $28 \mathrm{hr}$. The $\mathrm{pH}$ of such defibrinated blood was 7.8 at the beginning of the incubations and decreased to 7.4 at the end of $28 \mathrm{hr}$. Penicillin $(100$ $\mathrm{U} / \mathrm{ml})$ and streptomycin $(0.1 \mathrm{mg} / \mathrm{ml})$ were added to prevent bacterial contamination. In some experiments, $30 \mathrm{~mm}$ adenosine was added either at the beginning of the incubation or after a previous $24-28 \mathrm{hr}$ incubation designed to deplete the erythrocytes of ATP. When adenosine was added after previous depletion for $24-28 \mathrm{hr}$, the incubations were continued for $2 \mathrm{hr}$ in order to obtain maximal regeneration of erythrocyte ATP levels.

Red cell volume was measured through the use of microhematocrit and cell count determinations with a Coulter electronic particle counter. The whole blood hemoglobin determinations were carried out by the method of Crosby, Munn, and Furth (8) and ghost hemoglobins were measured as previously described (9). The relative changes in cell volume during incubation were determined by serial measurements of the ratio of hemoglobin/hematocrit ( $\mathrm{MCHC}$ ) and confirmed by observations of cell volume in $1 \% \mathrm{PO}_{4}$-buffered sodium chloride with an electronic particle counter system previously described (1).

Observations on cell shape were made by use of Zeiss phase microscope equipment described previously (1).

Red cell ATP measurements were carried out by the luciferin-luciferase assay method utilizing a liquid scintillation counter, as previously described (10).

Red cell calcium and magnesium were measured by atomic absorption flame photometry. The cells were washed three times with Tris-buffered sodium chloride, and 1 volume of cells lysed with 2 volumes of distilled, deionized water followed by an initial extraction with $1 \mathrm{ml}$ of $20 \%$ trichloroacetic acid (TCA) containing $0.5 \%$ lanthanum chloride. After centrifugation, the supernatant was transferred to a $10 \mathrm{ml}$ volumetric flask and the precipitate reextracted four times, each with $2 \mathrm{ml}$, to bring the volume to $10 \mathrm{ml}$. Lanthanum was essential to eliminate interference by phosphate or other anions. Each value given is the mean of determinations of triplicate extractions. In order to assure that calcium measured in the washed cells did not include external calcium precipitated by inorganic phosphate lost from depleted cells, parallel washes were carried out with Tris buffer, $\mathrm{pH} 6.8$, to enhance solubilization of any such precipitates. The cellular calcium values were unaffected by lowered $\mathrm{pH}$ of the wash solution, indicating that no significant precipitation had occurred.

Red cell viscosity measurements were made in a Brookfield Model LVT cone-plate viscometer ${ }^{1}$ having shear rates variable from 1.15 to $230 \mathrm{sec}^{-1}$, calibrated by use of Cannon Instrument $\mathrm{Co}^{2} 17$ and 580 centipoise $(\mathrm{cp})\left(37^{\circ} \mathrm{C}\right)$ standards and National Bureau of Standards $7.9 \mathrm{cp}\left(37^{\circ} \mathrm{C}\right)$ standard. Viscosity measurements of fresh and depleted cells, as well as of hemoglobin solutions from fresh and depleted cells, were also carried out with the GDM viscometer previously described (11). In order to minimize the effect of plasma protein-induced aggregation of red cells on the viscosity of red cell suspensions (12), the latter was measured with red cells which had been washed three times with a $300 \mathrm{mOsm}$ sodium chloride-Tris buffer, $\mathrm{pH} 7.4$. The viscosity measurements were carried out at $37^{\circ} \mathrm{C}$ on $80 \%$ cell suspensions prepared either in $1 \%$ serum albumin (human or bovine), in $\mathrm{NaCl}-\mathrm{Tr}$ is buffer, or in the latter alone. No difference was noted between the two suspending media, and both completely prevented rouleaux formation. The $80 \%$ hematocrit was chosen to enhance sensitivity of measurements at low shear rates and also because it was the highest hematocrit which was readily reproducible. Burton has emphasized the absolute necessity for deformability of red cells at hematocrits in excess of $60(13,14)$. Thus, the viscosity of such suspensions reflects the ability of the cells to slip by one another in the presence of close packing. An initial 2-5 min period of incubation and mixing at a shear rate of $11.5 \mathrm{sec}^{-1}$ was employed to avoid settling of red cells and to obtain maximal reproducibility.

In some experiments the washed cells were shipped by air from Rochester to Boston. During shipment they were main-

\footnotetext{
${ }^{1}$ Brookfield Engineering Laboratories, Inc., Stoughton, Mass.

${ }^{2}$ Cannon Instrument Co., State College, $\mathrm{Pa}$.
} 
tained at temperatures from $0-4^{\circ} \mathrm{C}$ for periods up to $4 \mathrm{hr}$. These suspensions were rewarmed to $37^{\circ} \mathrm{C}$ before the viscosity measurements were carried out. Values after rewarming were comparable to those obtained before cooling. Viscosity measurements were also carried out on ghosts prepared from fresh and depleted red cells by concentrating the ghosts to an $80 \%$ packed cell volume in each case before measuring the viscosity as described above. The viscosity of hemoglobin, free of membrane protein, was measured with hemoglobin prepared from fresh and 24-hr depleted cells by distilled water lysis ( 1 volume of cells and 2 volumes of $\mathrm{H}_{2} \mathrm{O}$ ), lowering the $\mathrm{pH}$ of the hemolysate to $\mathrm{pH} 4.8$ with acetic acid to achieve maximum insolubility of membrane protein (15), centrifugation at $35,000 \mathrm{~g}$ for $15 \mathrm{~min}$, followed by readjustment of $\mathrm{pH} 7.4$ with $0.1 \mathrm{~N} \mathrm{NaOH}$ and recentrifugation to remove any final insoluble material. Viscosity of the clear hemoglobin solutions was determined either on dilute solutions $(2.6 \mathrm{~g} / 100 \mathrm{ml})$ resulting from the above procedure, with the GDM viscometer, or reconcentrated by ultrafiltration to $26 \mathrm{~g} / 100 \mathrm{ml}$ and run in the Brookfield viscometer.

Red cell filterability was carried out according to the method of Teitel, Rudulesco, Nicolau, and Fotino (16-19) with Schleicher and Schull No. 589 white band filter paper. This paper is estimated by the manufacturer to have a mean pore diameter of $6.0 \mu$. However, the filters did permit passage of $25 \%$ of latex particles over a particle size range from 5-15 $\mu$, indicating that the paper had a rather wide distribution of pore sizes. As Teitel et al. have pointed out, there is considerable variability from one lot of paper to another requiring restandardization of normals with each lot. Although the use of $5 \mu$ Millipore filters for measuring red cell filterability as described by Jandl, Simmons, and Castle (20) allows more precise pore size estimation, the technique of Teitel was chosen because, in our hands, variable hemolysis was encountered with the Millipore filters, perhaps because of the presence of detergent which has been recently reported as present in such filters to increase their wettability (21). Recent careful quantitative studies by Gregerson, Chien, and colleagues (22-24) have documented the correlation between viscosity of suspensions with a hematocrit greater than $60 \%$ and the ability of cells to pass through filter papers having pore diameter less than $7 \mu$, the major diameter of normal erythrocytes.

The procedure itself consisted of pouring $2 \mathrm{ml}$ of an $80 \%$ suspension of washed cells into a cone of the specified filter paper, prewetted with saline-Tris buffer, $\mathrm{pH} 7.4$, and the volume passing through the filter was quantitated at 1,2 , 4,8 and 16 min. $t_{1}$ was calculated from semilog plots of time vs. flow rate. Since $2 \mathrm{ml}$ was always used in the same funnel, initial hydrostatic pressure was comparable in all cases.

Membrane deformability. The technique for measuring the pressures required to deform erythrocytes and erythrocyte ghosts is, in principle, similar to the micropipette method adopted by Rand and Burton $(25,26)$ from Mitchison and Swann (27). Washed intact cells and ghosts were suspended in a Tris- $\mathrm{NaCl}$ buffer $(\mathrm{pH} 7.4)$ contained in a chamber fitted on the phase microscope stage, rather than the hanging drop employed by Rand and Burton. For this reason, a water immersion, long-working distance objective was employed; final magnification achieved was $1000 \times$. The micropippette, supported by a deFonbrune-type micromanipulator, was connected to a small reservoir driven in the vertical plane by a micrometer screw in order to adjust to zero pressure in the micropipette and to measure extremely small pressures required to deform certain cells (one revolution of the screw $=1 \mathrm{~mm} \mathrm{H}_{2} \mathrm{O}$; the micrometer could be read to $0.01 \mathrm{~mm}$ ). The series-connected pipette and reservoir were connected to parallel water and mercury manometers, and valves were arranged such that deformation of a cell could be observed and the pressure read immediately from either the water or mercury manometer. All measurements were made at room temperature.

Pipettes drawn from $1 \mathrm{~mm}$ o.D. Kimball ${ }^{3}$ glass tubing 6088-D2 were selected for tip diameter of 3.0-3.5 $\mu$. The pipettes were filled with buffer and calibrated by comparing pressures required to deform fresh control erythrocytes from a single donor. Only those yielding pressures in the 3-6 $\mathrm{mm} \mathrm{H}_{2} \mathrm{O}$ range were utilized in these studies. Measurements of each individual cell diameter and pipette internal tip diameter were made by an eyepiece micrometer. Estimates were assumed to be within $\pm 10 \%$ of true values for the pipette internal diameter, as noted by Rand and Burton (25).

In each experiment involving intact erythrocytes, measurements made with fresh control cells preceded those observations recorded for depleted and (or) treated cells, and fresh control cells were observed again at the conclusion of the experiment. The same micropipette was employed throughout an experiment so that data from the control and experimental cells could be compared directly in such an experiment. When ghosts were under study, the control consisted of both intact fresh cells and fresh ghosts. The criterion for deformation of the erythrocytes or ghosts was taken as the the induction of a visible hemispherical portion of the cell in the pipette tip, the radius of such a bulging portion of the cell membrane being equal to one-half of the internal diameter of the pipette. The hemispherical deformation was entirely reversible, and the normal biconcave disc shape was restored, even after repeated attempts with the same fresh cell or a ghost prepared from a fresh cell. As noted by Rand and Burton (25) similar values were obtained at the rim or center of the biconcave fresh erythrocyte, and similar values were observed in all normal fresh cells studied. Since $\mathrm{P}=2 \mathrm{~T}\left(\frac{1}{\mathrm{R}_{\mathrm{p}}}-\frac{1}{\mathrm{R}_{\mathrm{c}}}\right)$, where $\mathrm{P}=$ pressure differential between the pipette and medium, $\mathrm{T}=$ tension in the membrane, and $R_{p}, R_{c}=$ radius of the pipette and cell, respectively, it is evident that some variation may be expected if substantial differences in pipette internal tip diameter occur. The pressures required to deform $20-50$ control cells were recorded for each of several pipettes with estimated diameters of 2.5-3.5 $\mu$. For pipettes having similar internal tips diameters, the range of values for $\mathrm{P}$ was the mean $\pm 10 \%$, a range not surprising in that the tip diameters may vary by $\pm 10 \%$, the error inherent in measuring such pipettes.

The reproducibility of control values in such pipettes justified comparisons between experiments performed with pipettes of the same nominal diameter. By contrast to fresh cells, the increasing membrane viscosity of depleted cells makes the deformation at a given pressure relatively more dependent on the rate of application of the pressure gradient. These experiments were intended to make relative comparisons between fresh, normal cells and depleted or altered cells. Therefore, membrane deformability has been expressed directly as the negative pressure required to produce immediate hemispherical deformation of the membrane into a standard pipette.

Cell electrophoresis was measured with the chamber described by Fuhrmann and Ruhenstroth-Bauer (28). Preliminary calibration of the chamber was carried out to avoid electroosmotic effects. Measurements were carried out both

\footnotetext{
${ }^{3}$ Owens-Illinois Glass Co., Toledo, Ohio.
} 
in an isotonic sodium phosphate buffer and also in a 0.03 M phosphate buffer plus 0.24 M sorbitol, used to decrease the ionic strength and thereby increase the sensitivity of the system. In all cases, the cells were washed three times before measurements were made, and the results have been corrected for the conductivity of the medium as described by Fuhrmann et al. (28). Each value reported represents 10 observations in both directions with successive measurements on the same cell being made after reversal of the polarity. The standard deviation of a single determination was $4.7 \%$.

The hemoglobin and nonhemoglobin protein content of the cell membrane were estimated by preparation of ghosts from fresh and depleted erythrocytes in an identical standardized fashion. 1 volume of washed red cells resuspended at a $50 \%$ hematocrit in $1 \%$ saline was added to 9 volumes of $30 \mathrm{mOsm}$ phosphate buffer. After centrifugation at $9000 \mathrm{~g}$ and removal of supernatant, subsequent treatment included one wash with 30 mOsm phosphate buffer ( 50 volumes of wash per 1 volume of cells) and a final wash with $1 \% \mathrm{NaCl}$-Tris buffer. Since it has been previously shown that the successive washes necessary to prepare white ghosts result in the loss of nonhemoglobin membrane protein (15) which might tend to minimize differences between fresh and depleted cells, and because it was desired to prepare ghosts which might reflect more closely the state of affairs in the intact cell, the two-step wash technique described was employed for protein determinations rather than the four-step wash used to prepare "white" ghosts. The hemoglobin content of the ghosts was estimated by the benzidine method of Bing and Baker (29) as modified by Dacie (30), and the nonhemoglobin protein of the ghosts was calculated by subtraction of hemoglobin from the total protein content determined by the Folin method (31).

Reconstituted ghosts were prepared from both fresh and depleted red cell utilizing the technique described by Hoffman (32). 1 volume of washed red cells was introduced into $10 \mathrm{ml}$ of distilled water containing no additives (as a control) or sufficient quantities of several agents to give final intracellular concentration as shown in Table IV. The lysed cell suspensions were allowed to stand for $10 \mathrm{~min}$, and then 0.1 volume of a $1.42 \mathrm{M}$ potassium chloride and $0.28 \mathrm{M}$ sodium chloride-containing solution was added to bring the final concentration of the medium to $142 \mathrm{~mm}$ potassium and 24 mM sodium. The preparation was then incubated for periods of time varying from $20 \mathrm{~min}$ to $2 \mathrm{hr}$, centrifuged, and resuspended in isotonic $\mathrm{NaCl}-\mathrm{Tr}$ is buffer ( $\mathrm{pH} \mathrm{7.4)}$ for deformability measurements by use of the micropipette. However, any changes that occurred became apparent by $30 \mathrm{~min}$ and, therefore, the latter time was selected for comparative studies. The preparations were stored at $4^{\circ} \mathrm{C}$ after the resuspension step until deformability measurements were made to minimize any changes which might have occurred with standing. The cells were brought back to room temperature for the measurements.

\section{RESULTS}

Red cell viscosity. Fig. 1 is a Casson plot (square root of shear stress vs. square root of shear rate) representing measurement of viscosity made both with the GDM and Brookfield viscometers on samples of fresh and depleted cells. Additional data are included on viscosity measurements of a hemoglobin solution isolated from ATP-depleted cells freed of membrane protein by

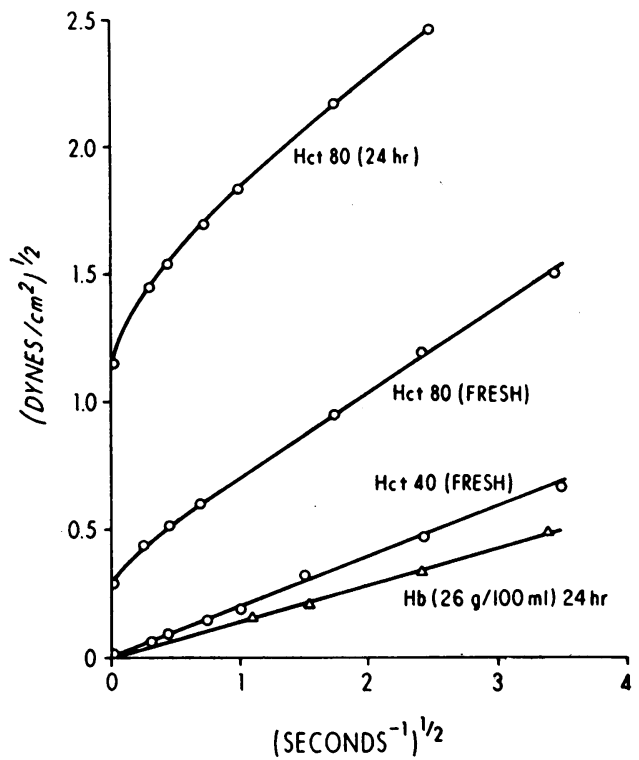

Figure 1 Casson plot of viscosity of fresh and depleted red cell suspensions. The viscosity of suspensions of washed red cells was measured with the GDM viscometer, and the hemoglobin solution was freed of membranes, concentrated by ultrafiltration, and viscosity measured with the cone-plate viscometer.

lowering $\mathrm{pH}$ to 4.8 (15) and centrifugation. The $\mathrm{pH}$ was readjusted to 7.4 with Tris, the hemoglobin reconcentrated by ultrafiltration to $26 \mathrm{~g} / 100 \mathrm{ml}$, and viscosity measured with the cone-plate viscometer.

Fig. 1 illustrates several important points: for suspensions with hematocrits of $80 \%$ there is nonlinearity of

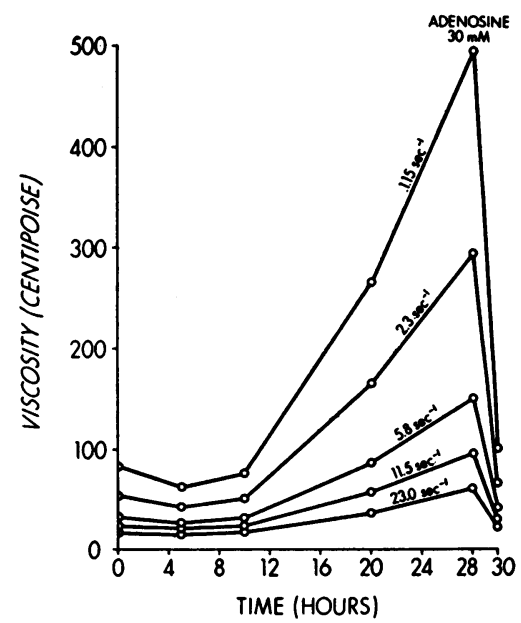

FIGURE 2 Changes in viscosity of erythrocyte suspensions with time. Viscosity of $80 \%$ suspensions of red cells in saline-Tris buffer, $\mathrm{pH} 7.4$, measured at varying shear rates is plotted over $30 \mathrm{hr}$ of incubation of defibrinated blood. $30 \mathrm{~mm}$ adenosine was added at $28 \mathrm{hr}$. Each point represents the mean of five separate incubations. 
the Casson plot which increases after incubation, indicating non-Newtonian behavior ${ }^{4}$ as does the fact that extrapolation of the curve to zero shear rate does not show a zero intercept. The positive shear stress intercept at zero shear is indicative of a yield stress. Yield stress is virtually absent from fresh cells suspended at $40 \%$ hematocrit and hemoglobin solutions of $26 \mathrm{~g} / 100 \mathrm{ml}$ but identifiable in the $80 \%$ red cell suspensions. Most striking, however, is the fourfold increase in yield stress evident in the 24-hr depleted red cells. With the GDM viscometer, no differences were apparent in the viscosity characteristics of a $2.5 \mathrm{~g} / 100 \mathrm{ml}$ solution of hemoglobin isolated from fresh and depleted red cells. Previous work (12) has indicated that the non-New-

\footnotetext{
- The criteria for Newtonian properties (viscosity not dependent on shear rate) are: (a) linearity of the data on a Casson plot and $(b)$ the line representing data passes through the origin. When these requirements are met, the slope of the line is the square root of the Newtonian viscosity in poise.
}

tonian viscosity characteristics of whole blood at physiological hematocrits can be attributed largely to fibrinogen-dependent rouleaux formation and that washed red cells resuspended in isotonic buffered saline at the same hematocrit do not manifest the same shear-dependent viscosity. By phase microscopy no cell-cell aggregation was apparent in the shear-dependent suspensions with hematocrits $>60$. However, in order to exclude the possibility that the shear dependence of the washed suspensions reflected the presence in the medium of some cellular material, such as small amounts of hemoglobin which might promote cell-cell interaction, cells were washed six times rather than three times with no change in viscosity. Similarly, addition of hemolysate to the suspensions in amounts up to those which would be found if $3 \%$ hemolysis had occurred during the viscosity determination itself produced no alteration in the measurements. In 28 -hr samples, $1-4 \%$ hemolysis was encountered after the cells were exposed to shear rates of

TABLE I

Changes in Erythrocyte Viscosity, Calcium, ATP, and Membrane Deformability during Incubation

\begin{tabular}{|c|c|c|c|c|}
\hline Time of Incubation & ATP & Viscosity & $\mathrm{Ca}$ & $\begin{array}{c}\text { Membrane } \\
\text { deformability }\end{array}$ \\
\hline$h r$ & moles $/$ liter $\times 10^{-8}$ & cps at $1.15 \mathrm{sec}^{-1}$ & moles $/$ cell $\times 10^{-18}$ & $P$ in $m m H_{2} \mathrm{O}$ \\
\hline 0 & $\begin{array}{c}1.64 \pm 0.07 \\
(n=5)\end{array}$ & $\begin{array}{l}77 \pm 8 \\
(n=9)\end{array}$ & $\begin{array}{r}5.8 \pm 0.4 \\
(n=34)\end{array}$ & $\begin{array}{r}4.1 \pm 0.09 \\
(n=178)\end{array}$ \\
\hline 5 & $\begin{array}{c}1.22 \pm 0.11 \\
(n=5)\end{array}$ & $\begin{array}{l}57 \pm 7 \\
(\mathrm{n}=10)\end{array}$ & & $\begin{array}{r}8.0 \pm 0.15 \\
(n=114)\end{array}$ \\
\hline 10 & $\begin{array}{c}0.25 \pm 0.09 \\
(n=4)\end{array}$ & $\begin{array}{l}72 \pm 8 \\
(n=9)\end{array}$ & $\begin{array}{r}6.8 \pm 0.8 \\
(n=8)\end{array}$ & $\begin{array}{r}10.4=0.12 \\
(n=119)\end{array}$ \\
\hline 15 & & $\begin{array}{r}170 \pm 51 \\
(n=3)\end{array}$ & & $\begin{array}{r}14.8 \pm 0.21 \\
(n=114)\end{array}$ \\
\hline 20 & & $\begin{array}{r}274 \pm 28 \\
(\mathrm{n}=8)\end{array}$ & $\begin{array}{r}13.8 \pm 1.8 \\
(n=4)\end{array}$ & $\begin{array}{c}44.7 \pm 1.08 \\
(n=80)\end{array}$ \\
\hline 24 & 0 & $\begin{array}{r}391 \pm 12 \\
(n=6)\end{array}$ & $\begin{array}{r}18.3 \pm 3.4 \\
(n=10)\end{array}$ & $\begin{array}{c}59.2 \pm 0.72 \\
(n=89)\end{array}$ \\
\hline $\begin{array}{l}24+2 \mathrm{hr} \text { with } \\
30 \mathrm{~mm} \text { adenosine }\end{array}$ & $\begin{array}{c}0.68 \pm 0.06 \\
(n=4)\end{array}$ & $\begin{array}{r}118=11 \\
(n=5)\end{array}$ & $\begin{array}{r}9.8 \pm 1.2 \\
(n=7)\end{array}$ & $\begin{array}{c}5.1 \pm 0.36 \\
(n=20)\end{array}$ \\
\hline $\begin{array}{l}24+2 \mathrm{hr} \text { with } \\
\quad 30 \mathrm{mM} \text { adenosine }+ \\
10^{-4} \mathrm{M} \text { ouabain }\end{array}$ & $\begin{array}{c}0.44 \pm 0.07 \\
(n=4)\end{array}$ & $\begin{array}{l}112 \pm 4 \\
(n=4)\end{array}$ & $\begin{array}{r}11.5 \pm 1.0 \\
(n=3)\end{array}$ & \\
\hline $\begin{array}{l}24+10^{-3} \times \text { ATP } \\
\text { added to medium }\end{array}$ & & $\begin{array}{c}455 \\
(n=1)\end{array}$ & & $\begin{array}{c}51.7 \pm 0.36 \\
(n=15)\end{array}$ \\
\hline 28 & & $\begin{array}{l}520 \pm 47 \\
(n=11)\end{array}$ & $\begin{aligned} & 27.1 \pm 6.0 \\
&(n=24)\end{aligned}$ & $\begin{array}{r}58.4 \pm 2.05 \\
(n=21)\end{array}$ \\
\hline $\begin{array}{c}28+2 \mathrm{hr} \text { with } 30 \\
\text { mM adenosine }\end{array}$ & & $\begin{array}{r}110 \pm 12 \\
(n=8)\end{array}$ & $\begin{aligned} & 18.3 \pm 2.3 \\
&(n=14)\end{aligned}$ & $\begin{array}{c}5.1 \pm 0.28 \\
(n=90)\end{array}$ \\
\hline
\end{tabular}

ATP, adenosine triphosphate.

Values are reported \pm SE. 
$230 \mathrm{sec}^{-1}$. Fig. 2 and Table I detail the time-dependent changes in viscosity of $80 \%$ cell suspensions measured at varying shear rates. Fig. 2 emphasizes that although there is a distinct increase in viscosity seen with time at the highest shear rate, the most marked increases in viscosity are seen at the lowest shear rates beginning after $10 \mathrm{hr}$. In addition, striking reversal of the viscosity of depleted cells is seen at all shear rates after further incubation with $30 \mathrm{~mm}$ adenosine.

Although, as mentioned in Methods, detailed comparisons of viscosity and filterability of reconstituted ghosts were not feasible because of cell volume differences, a qualitative comparison was made between the viscosity of an $80 \%$ suspension of ghosts prepared from 24-hr depleted cells. Although the viscosity of ghost suspensions was less than that of comparable suspensions of intact cells, Fig. 3 illustrates that a marked increase in both viscosity and non-Newtonian properties was evident in the ghosts prepared from ATP-depleted cells in contrast to those prepared from fresh red cells. When ghosts were prepared from fresh cells and then incubated as ghosts for $24 \mathrm{hr}$ in $300 \mathrm{mOsm} \mathrm{NaCl-Tris} \mathrm{buffer,} \mathrm{pH} 7.4$, the viscosity did not increase, a finding indicating that the increased viscosity of a suspension of ghosts from depleted cells must depend on changes in the soluble interior of intact cells and (or) the presence of serum (containing calcium).

Red cell calcium and magnesium. Fig. 4 and Table 1 compare changes in low shear rate viscosity, red cell calcium, ATP, and membrane deformability at selected times during incubation. It seems clear that little change in viscosity or red cell calcium occurs until ATP levels fall to below $15 \%$ of initial values. However, at that point, the red cells begin to accumulate calcium progressively. If one were to express the calcium values and units of concentration per liter of red cells rather than

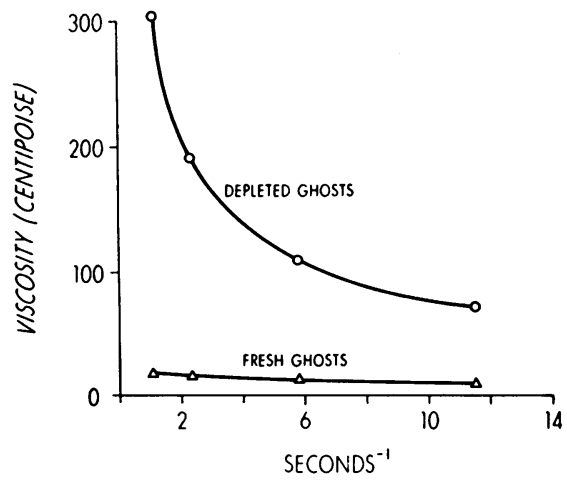

FIGURE 3 Viscosity of ghosts prepared from fresh and adenosine triphosphate (ATP)-depleted cells. Ghosts were prepared from fresh red cells and from cells at the end of a $24 \mathrm{hr}$ incubation. The viscosity of $80 \%$ suspensions was measured in the cone-plate viscometer.

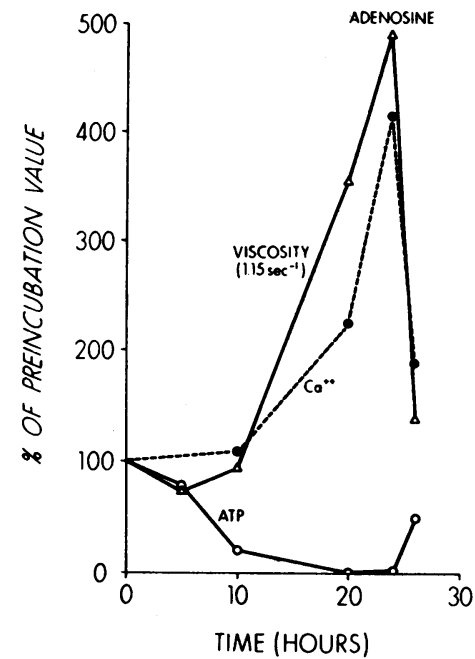

FIGURE 4 Changes in erythrocyte viscosity, calcium, and ATP occurring with in vitro incubation. Values are expressed as per cent of preincubation values. Viscosity values of $80 \%$ suspensions of red cells in saline-Tris buffer, $\mathrm{pH} 7.4$, were measured at $1.15 \mathrm{sec}^{-1}$ shear rate. The mean preincubation values for viscosity were $77 \pm 8$ (SE) cp. Preincubation values for calcium were $5.8 \pm 0.4(\mathrm{SE}) \times 10^{-18}$ moles/cell.

moles per cell, comparable values would range between $8 \times 10^{-5} \mathrm{M}$ for fresh red cells to $3.5 \times 10^{-4} \mathrm{M}$ for depleted cells. However, since much of the calcium is associated with the membrane, it is probably not valid to express the values in terms of moles per liter of red cells. Although it is difficult to assess intracellular localization at each point, $>60 \%$ of measurable total cellular calcium was found in ghosts from the same cells, a finding indicating that the major share of increased cellular calcium was found in the membrane in such a fashion as to resist removal by osmotic lysis.

By contrast to changes in cellular calcium, the magnesium of washed fresh cells was found to be $2.10 \pm 0.09$ $(\mathrm{SE}) \times 10^{-16} \mathrm{moles} / \mathrm{cell}(\mathrm{n}=6)$ and $1.90 \pm 0.05(\mathrm{SE}) \times$ $10^{-16}$ moles/cell $(\mathrm{n}=24)$ after $24 \mathrm{hr}$ of incubation without added substrate. The latter value was not significantly different from fresh cell values. Magnesium values after incubation of ATP-depleted cells with $30 \mathrm{~mm}$ adenosine for $2 \mathrm{hr}$ were $1.95 \pm 0.16(\mathrm{SE}) \times 10^{-16} \mathrm{moles} /$ cell $(n=6)$. Thus, in contrast to magnesium which does not change significantly, calcium accumulation appears to parallel the changes in viscosity and to follow ATP depletion. Reversal toward normal of viscosity and calcium levels at $24 \mathrm{hr}$ accompanies partial regeneration of ATP levels. By $28 \mathrm{hr}$, however, only partial reversal of total cellular calcium content follows incubation with adenosine, in contrast to the major reversal of viscosity and filterability.

Membrane deformability of intact cells is shown in 
TABLE II

Changes in Membrane Deformability of Intact Erythrocytes

\begin{tabular}{|c|c|c|c|}
\hline $\begin{array}{l}\text { Time of } \\
\text { incubation }\end{array}$ & $\mathbf{P}$ & $\mathbf{S E}$ & $\mathrm{n}$ \\
\hline$h r$ & $m m \mathrm{H}_{2} \mathrm{O}$ & & \\
\hline 0 & 4.1 & 0.09 & 178 \\
\hline 1 & 4.0 & 0.08 & 89 \\
\hline 2 & 4.0 & 0.08 & 89 \\
\hline 3 & 4.2 & 0.08 & 102 \\
\hline 4 & 6.7 & 0.15 & 102 \\
\hline 5 & 8.0 & 0.15 & 114 \\
\hline 6 & 8.6 & 0.12 & 107 \\
\hline 7 & 10.1 & 0.10 & 113 \\
\hline 8 & 9.8 & 0.09 & 121 \\
\hline 9 & 10.1 & 0.16 & 114 \\
\hline 10 & 10.4 & 0.15 & 119 \\
\hline 11 & 11.3 & 0.21 & 121 \\
\hline 12 & 12.0 & 0.15 & 114 \\
\hline 13 & 12.3 & 0.16 & 114 \\
\hline 14 & 13.1 & 0.28 & 114 \\
\hline 15 & 14.8 & 0.21 & 114 \\
\hline 16 & 16.5 & 0.31 & 114 \\
\hline 17 & 19.4 & 0.48 & 114 \\
\hline 18 & 22.3 & 0.47 & 114 \\
\hline 19 & 29.3 & 0.61 & 93 \\
\hline 20 & 44.7 & 1.08 & 80 \\
\hline 24 & 50.2 & 0.72 & 89 \\
\hline
\end{tabular}

Measurements were made on red cells incubated, washed, and resuspended in $\mathrm{pH} 7.4 \mathrm{NaCl}$-Tris buffer at times indicated. Membrane deformability is expressed as the mean negative pressure $(\mathrm{P})$ necessary to produce hemispherical deformation of the red cell membrane into a $3 \mu$ micropipette. The data represent measurements on cells from five different individuals.

Fig. 5 for a representative incubation. Table II summarizes the data from all experiments in which the red cells were incubated for $24 \mathrm{hr}$. Between 4 and $6 \mathrm{hr}$ there was a highly significant $(P<0.01) 100 \%$ increase in the deforming pressure. These changes occurred before any morphologic change was apparent. After $6 \mathrm{hr}$ no further change occurred until after $10 \mathrm{hr}$. In fully depleted cells $(>24 \mathrm{hr}$ ) increasing pressures did not induce the formation of a long "tongue" of membrane within the pipette; and if extreme pressures were employed, a spherical ghost was formed. The deformability of various cells within the population at each stage of depletion was quite homogeneous.

Cells suspended in unbuffered isotonic $\mathrm{NaCl}$ ( $\mathrm{pH}$ 6.25) required pressures two to three times greater than those required for deformation at $\mathrm{pH}$ 7.4.

Table III illustrates the effect (or lack of effect) of incubation of cells with various agents. Incubation of 24-hr depleted red cells for $2 \mathrm{hr}$ with $30 \mathrm{~mm}$ adenosine restored values for membrane deformability to fresh cell

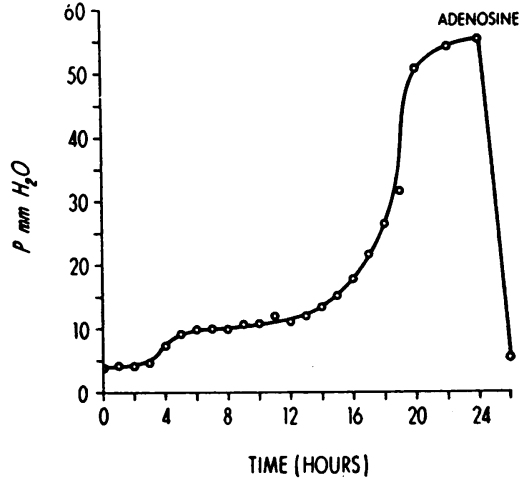

FIGURE 5 Changes in red cell membrane deformability with in vitro incubation. The negative pressures required for deformation of the membrane into a $3 \mu$ micropipette are plotted against time of incubation for a representative blood sample. Each point of the graph represents the mean of measurements on $20-50$ cells made at each time during incubation.

values. Table III also indicates that ATP added to the medium at the end of $24 \mathrm{hr}$ was without effect. However, when $5 \times 10^{-8} \mathrm{M}$ ethylenediamine tetraacetate (EDTA) was present throughout membrane deformability did not become as strikingly abnormal.

TABLE III

Effect of Incubation of Cells with Various Agents

\begin{tabular}{|c|c|c|c|}
\hline & $\mathbf{P}$ & SE & $\mathbf{n}$ \\
\hline \multicolumn{4}{|c|}{$m m \mathrm{H}_{2} \mathrm{O}$} \\
\hline Fresh cells & 4.1 & 0.09 & 178 \\
\hline $\begin{array}{l}\text { Cells depleted for } \\
24 \mathrm{hr}\end{array}$ & 48.1 & 0.61 & 157 \\
\hline $\begin{array}{l}\text { Cells depleted for } \\
24 \text { hr with } 30 \mathrm{~mm} \\
\text { adenosine }\end{array}$ & 5.1 & 0.23 & 110 \\
\hline $\begin{array}{l}\text { Cells depleted for } \\
24 \mathrm{hr} \text { in presence of } \\
5 \times 10^{-3} \mathrm{M} \text { EDTA }\end{array}$ & 11.5 & 0.93 & 50 \\
\hline $\begin{array}{l}\text { Cells depleted for } \\
24 \mathrm{hr}+2 \mathrm{hr} \\
\text { with } 10^{-3} \mathrm{M} \text { ATP }\end{array}$ & 51.7 & 0.36 & 15 \\
\hline $\begin{array}{l}\text { Cells depleted for } \\
24 \mathrm{hr}+2 \mathrm{hr} \\
\text { with } 2 \times 10^{-2} \text { M ATP }\end{array}$ & 49.7 & 2.55 & 13 \\
\hline $\begin{array}{l}\text { Fresh cells treated } \\
\text { with } \mathrm{CN}^{-}\end{array}$ & 3.5 & 0.21 & 11 \\
\hline $\begin{array}{l}\mathrm{CN}^{-} \text {treated cells, de- } \\
\text { pleted for } 24 \mathrm{hr}\end{array}$ & 47.0 & 2.75 & 12 \\
\hline
\end{tabular}

ATP, adenosine triphosphate; EDTA, ethylenediamine tetraacetate; $C N$, cyanide. $P$ represents mean pressure necessary to deform the membrane. 
TABLE IV

Membrane Deformability of Red Cell Ghosts

\begin{tabular}{|c|c|c|c|}
\hline & $P$ & SE & $\mathbf{N}$ \\
\hline \multicolumn{4}{|l|}{$\begin{array}{l}\text { Reconstituted ghosts prepared } \\
\text { from fresh cells }\end{array}$} \\
\hline $\begin{array}{l}\text { Control, no additive } \\
+10^{-4} \mathrm{M} \mathrm{Ca} \\
+10^{-4} \mathrm{M} \mathrm{Ca} \text { and } 10^{-3} \mathrm{M} \text { ATP } \\
+10^{-4} \mathrm{M} \mathrm{Ca} \text { and } 10^{-3} \mathrm{M} \text { EDTA } \\
+10^{-4} \mathrm{M} \mathrm{Ca} \text { and } 10^{-3} \mathrm{M} \mathrm{Mg} \\
+1 \mathrm{mM} \mathrm{NADP} \\
+1 \mathrm{mM} \mathrm{NAD}\end{array}$ & $\begin{array}{r}4.2 \\
352.0 \\
4.3 \\
4.7 \\
4.2 \\
6.8 \\
6.2\end{array}$ & $\begin{array}{r}0.10 \\
10.00 \\
0.15 \\
0.27 \\
0.19 \\
0.52 \\
0.38\end{array}$ & $\begin{array}{r}108 \\
96 \\
29 \\
29 \\
50 \\
11 \\
11\end{array}$ \\
\hline \multicolumn{4}{|l|}{$\begin{array}{l}\text { Reconstituted ghosts prepared } \\
\text { from } 24 \text {-hr depleted cells }\end{array}$} \\
\hline $\begin{array}{l}\text { Control, no additive } \\
+10^{-3} \mathrm{M} \text { ATP } \\
+10^{-3} \mathrm{M} \text { EDTA } \\
+10^{-3} \mathrm{M} \mathrm{Mg} \\
+1 \mathrm{~mm} \mathrm{NADPH} \\
+1 \mathrm{mM} \text { NADH } \\
+10^{-3} \mathrm{M} \text { UTP } \\
+10^{-3} \mathrm{M} \text { GTP } \\
+10^{-3} \mathrm{MTP} \\
+10^{-3} \mathrm{M} \text { ADP } \\
+3 \times 10^{-3} \mathrm{M} \text { ADP } \\
+5 \times 10^{-3} \mathrm{M} \mathrm{GSH}\end{array}$ & $\begin{array}{r}51.2 \\
4.5 \\
4.1 \\
9.5 \\
58.5 \\
64.5 \\
49.2 \\
50.1 \\
66.6 \\
53.6 \\
58.7 \\
47.8\end{array}$ & $\begin{array}{l}1.21 \\
0.12 \\
0.15 \\
1.10 \\
4.20 \\
2.89 \\
2.99 \\
1.92 \\
6.00 \\
4.71 \\
3.30 \\
1.61\end{array}$ & $\begin{array}{r}58 \\
109 \\
30 \\
12\end{array}$ \\
\hline \multicolumn{4}{|l|}{ Hemoglobin-free ghosts } \\
\hline $\begin{array}{l}\text { Prepared from fresh cells } \\
\text { Prepared from 24-hr } \\
\text { depleted cells }\end{array}$ & 24.3 & 1.05 & 30 \\
\hline $\begin{array}{l}\text { Prepared from fresh cells, in- } \\
\text { cubated } 24 \mathrm{hr}+10^{-4} \mathrm{M} \mathrm{Ca}\end{array}$ & 33.3 & 0.55 & 50 \\
\hline $\begin{array}{l}\text { Prepared from fresh cells, in- } \\
\text { cubated } 24 \mathrm{hr}+10^{-4} \mathrm{M} \mathrm{Ca} \\
\quad+10^{-3} \mathrm{M} \mathrm{Mg}\end{array}$ & 5.6 & 0.36 & 50 \\
\hline
\end{tabular}

ATP, adenosine triphosphate; EDTA, ethylenediamine tetraacetate; NAD, nicotinamide adenine dinucleotide; NADP, NAD phosphate; NADPH, NADP, reduced form; UTP, uridine triphosphate; GTP, guanosine triphosphate; ITP, inosine triphosphate; ADP, adenosine diphosphate; GSH, glutathione, reduced from.

Reconstituted ghosts were prepared to contain various constituents by lysis of $1 \mathrm{vol}$ of packed red cells in $10 \mathrm{vol}$ of distilled, deionized water containing sufficient quantities of each agent to give the final concentrations indicated. Hemoglobinfiee ghosts were prepared by successive, hypotonic osmotic lysis and repeated washing. All ghosts then were resuspended

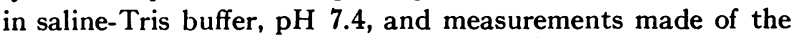
negative pressure required to deform the membrane into a $3 \mu$ micropipette. $\mathrm{P}$ represents mean negative deforming pressure.

Membrane deformability of erythrocyte ghosts. The separate contribution of the membrane itself, rather than the intracellular contents, to cell deformability was tested by applying micropipette measurements to erythrocyte ghosts (Table IV). Comparisons were also made with ghosts prepared from fresh and depleted cells, with the ghosts reconstituted to contain various desired compounds. Ghosts from fresh cells were reconstituted with calcium, calcium plus ATP, calcium plus EDTA, and calcium plus magnesium. Deformability of ghosts prepared from depleted red cells was the same as that of the depleted cells from which they were prepared, while incorporation of $1 \mathrm{~mm} \mathrm{ATP}$ or $1 \mathrm{~mm}$ EDTA restored the deforming pressure to normal levels, and reconstitution with magnesium restored deforming pressure to the $6 \mathrm{hr}$ level.

Although prolonged incubation of red cells in the absence of substrate produced major metabolic alterations other than ATP depletion, Table IV indicates that reconstitution of ghosts with nicotinamide adenine dinucleotide (NAD), NAD, reduced form (NADH), NAD phosphate (NADP), NADP, reduced form (NADPH), and glutathione, reduced form (GSH) is without effect on the deformability. Table IV also demonstrates the specificity of ATP and ineffectiveness of uridine tri-

TABLE V

Comparison of Changes in Filterability and Cell Volume during Incubation

\begin{tabular}{ccc}
\hline Time & Filterability t & Volume \\
\hline$h r$ & $\min$ & $\mu^{3}$ \\
& $8.7 \pm 1.7$ & $86.7 \pm 0.8$ \\
5 & $(\mathrm{n}=7)$ & $(\mathrm{n}=11)$ \\
& $9.0 \pm 1.0$ & $86.7 \pm 0.7$ \\
10 & $(\mathrm{n}=9)$ & $(\mathrm{n}=5)$ \\
& $21.8 \pm 4.8$ & $89.7 \pm 0.7$ \\
20 & $(\mathrm{n}=9)$ & $(\mathrm{n}=5)$ \\
& $>100$ & $101.8 \pm 2.1$ \\
24 & $(\mathrm{n}=5)$ & $(\mathrm{n}=5)$ \\
& $\infty$ & $96.0 \pm 1.0$ \\
28 & $(\mathrm{n}=6)$ & $(\mathrm{n}=5)$ \\
& $\infty$ & $94.7 \pm 1.4$ \\
$28+2$ hr with & $(\mathrm{n}=6)$ & $(\mathrm{n}=5)$ \\
30 mM adenosine & $23.6 \pm 9.6$ & $87.9 \pm 1.0$ \\
$28+2$ hr with & $(\mathrm{n}=5)$ & $(\mathrm{n}=5)$ \\
$30 \mathrm{~mm}$ adenosine & $(\mathrm{n}=1)$ & 81.7 \\
+0.1 mM oua- & & $(\mathrm{n}=2)$ \\
bain & &
\end{tabular}

Serial filterability observations were made over a $16 \mathrm{~min}$ period and extrapolated to $t_{1}$ from a semilog plot of the data. Values over $100 \mathrm{~min}$ are reported as $>100$ or $\infty$ (when no blood passed the filter). Where appropriate, values are reported $\pm \mathrm{SE}$. For the experiment in which depleted cells were incubated with adenosine and ouabain, the parallel control (adenosine alone) also had a filterability $t_{i}$ of $38 \mathrm{~min}$. 
phosphate (UTP), guanosine triphosphate (GTP), ana inosine triphosphate (ITP).

Reconstitution of fresh ghosts with calcium produced extremely unyielding membranes, which required the highest pressures recorded in these experiments to produce deformation. This result stands in clear, unmistakable contrast to the effect of magnesium. The ameliorating effects of ATP and magnesium in ghosts from depleted cells may be the result of reduction in membrane calcium content by chelation and mass action competition respectively. A similar effect produced in depleted ghosts by EDTA provides support for the interpretation that ATP effect results from the chelating action of ATP. The experiments with ghosts from fresh cells in which simultaneous introduction of ATP, EDTA, or magnesium with calcium prevents or minimizes (in the case of magnesium) the calcium effect also support this interpretation.

Filterability and cell volume. Table V summarizes changes in mean cell volume and filterability. Fig. 6 compares the time course of changes in low shear rate viscosity, mean cell volume, and filterability expressed as $\mathrm{t}_{1}$ for passage of $2 \mathrm{ml}$ of a suspension ( $80 \%$ hematocrit) of washed red cells through the No. 589 white band, Schleicher and Schull filter paper. Although ATP depletion is associated with an increase in cell volume of approximately $17 \%$ over $20 \mathrm{hr}$ of incubation, a reversal of the volume changes is apparent thereafter. The work of Meiselman et al. (33) suggests that the increase in cell volume may tend to obscure any early rise in intrinsic cellular viscosity. The $t$ for filterability has begun to increase by $10 \mathrm{hr}$ and continues to rise to $\infty$ by $24 \mathrm{hr}$, even after cell volume begins to decrease again. Adenosine produces a marked reversal toward normal at 24 and $28 \mathrm{hr}$.

Cell surface charge. Table VI compares electrophoretic mobility, viscosity, filterability, and membrane

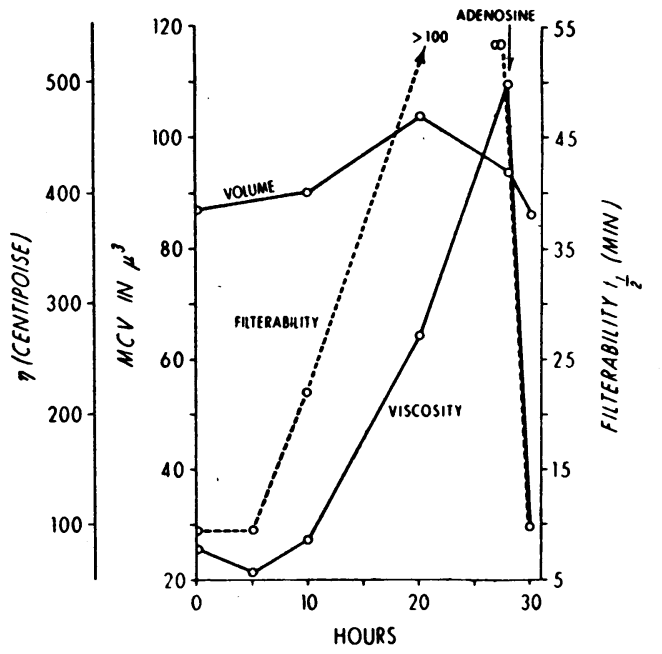

FIGURE 6 Changes in cell volume, viscosity, and filterability occurring with incubation. Volume is expressed as $\mu^{\mathbf{2}}$; viscosity of an $80 \%$ suspension in centipoise and filterability as $\mathrm{t}_{\mathrm{t}}$ for $2 \mathrm{ml}$ of an $80 \%$ suspension of washed cells to pass through No. 589 Schleicher and Schull, white band filter paper. Each point represents the mean of five or more determinations.

deformability data on fresh and depleted cells. It seems clear that under the conditions of measurement there is little net change in the zeta potential of ATP-depleted cells at $24 \mathrm{hr}$. In addition, experiments were conducted in which fresh and depleted cells were incubated with 5000 $\mathrm{U} / 100 \mathrm{ml}$ of neuraminidase with a resultant $75 \%$ decrease in electrophoretic mobility; but no change was observed in membrane deformability, viscosity, or filterability at either zero time or $24 \mathrm{hr}$, a finding providing further evidence that change in these properties is not dependent on altered cell surface charge.

Ouabain. Tables $\mathrm{I}$ and $\mathrm{V}$ indicate that oubain does not interfere with the reversibility of viscosity, filtera-

TABLE VI

Comparison of Electrophoretic Mobility of Fresh and Depleted Cells and of Viscosity, Filterability and Membrane Deformability of Fresh and Depleted Cells with Surface Charge Lowered by Treatment with Neuraminidase

\begin{tabular}{|c|c|c|c|c|}
\hline & Fresh & $\underset{\text { neuraminidase }}{\text { Fresh }+}$ & Depleted, 28 hr & $\underset{\text { neuraminidase }}{24 \mathrm{hr}}+$ \\
\hline Mobility, $\mu / \mathrm{sec} / \mathrm{volt} / \mathrm{cm}$ & $\begin{array}{c}2.09 \pm 0.03 \\
(n=7)\end{array}$ & $\begin{array}{c}0.52 \pm 0.05 \\
(n=5)\end{array}$ & $\begin{array}{c}2.13 \pm 0.03 \\
(n=7)\end{array}$ & $\begin{array}{l}0.51 \\
(n=2)\end{array}$ \\
\hline$\eta, \mathrm{cps}, 2.3 \mathrm{sec}^{-1}$ & $\begin{array}{c}54.00 \pm 8.47 \\
(n=7)\end{array}$ & $\begin{array}{c}54,71 \\
(n=2)\end{array}$ & $334 \pm 71.99$ & $\begin{array}{l}334 \\
(n=2)\end{array}$ \\
\hline Filterability, $t_{\mathfrak{l}}, \min$ & $\begin{array}{c}7.9 \pm 0.62 \\
(\mathrm{n}=7)\end{array}$ & $\begin{array}{c}9.7 \\
(n=2)\end{array}$ & $\infty$ & $\infty$ \\
\hline Membrane deforming pressure, $\mathrm{mm}$ of $\mathrm{H}_{2} \mathrm{O}$ & $\begin{array}{c}4.3 \pm 0.15 \\
(n=41)\end{array}$ & $\begin{array}{c}3.9 \pm 0.29 \\
(n=49)\end{array}$ & $\begin{array}{c}48.3 \pm 1.64 \\
(n=21)\end{array}$ & $\begin{array}{c}48.0 \pm 1.37 \\
(n=21)\end{array}$ \\
\hline
\end{tabular}



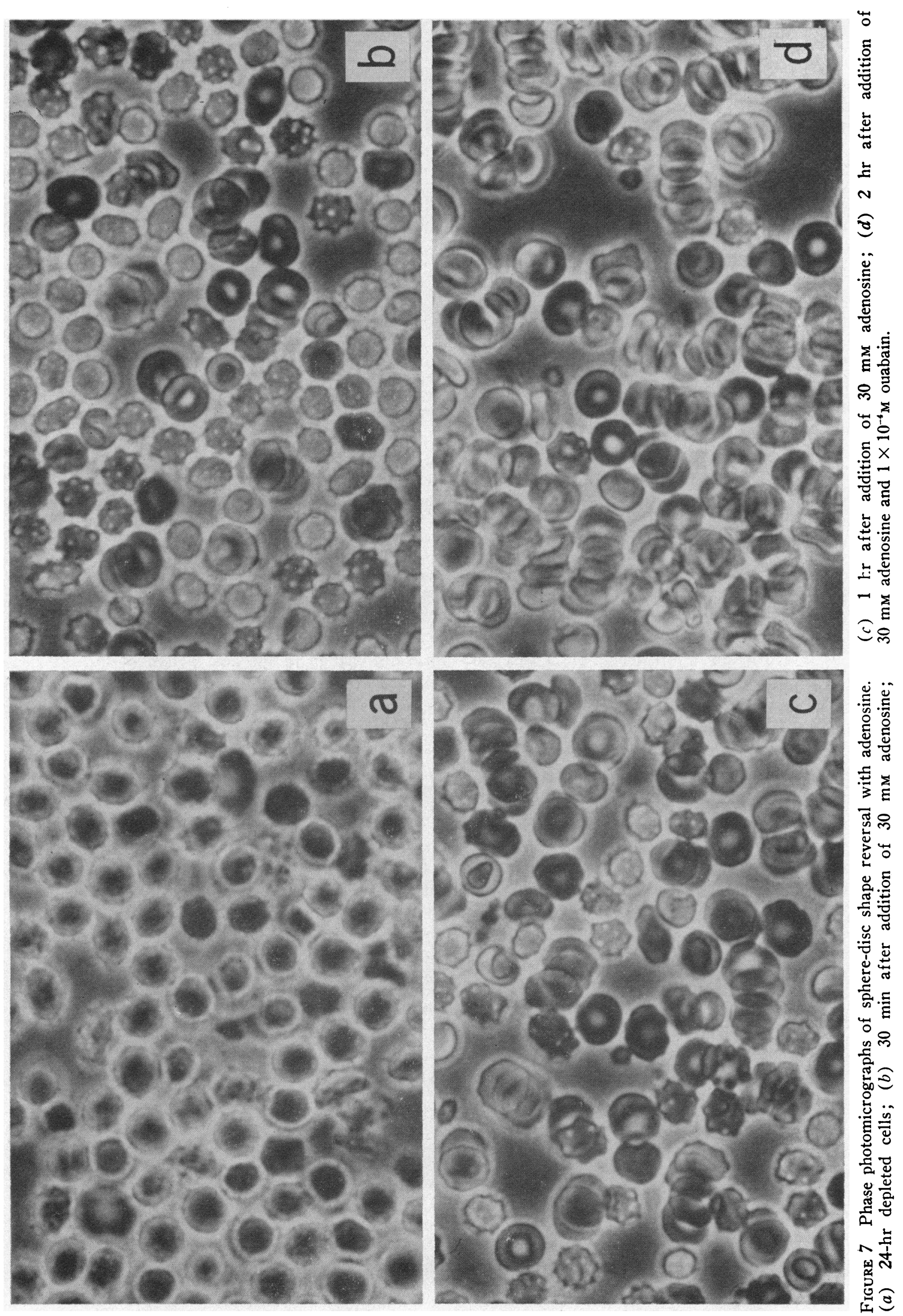
bility, or membrane deformability, a finding indicating that none of these parameters are dependent on the ouabain-inhibitable sodium-potassium pump.

Cell shape. Red cells incubated in serum for $24 \mathrm{hr}$ were found to have assumed a crenated spherical configuration which was reversible upon addition of adenosine in a manner analogous to Nakao's observations with adenine plus inosine (34). $1 \times 10^{-4} \mathrm{M}$ ouabain was found to have no effect on the reversibility of the shape changes illustrated in Fig. 7.

Hemoglobin and nonhemoglobin protein. Table VII summarizes data on the hemoglobin and nonhemoglobin protein content of ghosts prepared from fresh cells and from cells after $24 \mathrm{hr}$ of incubation. Ghosts prepared from depleted red cells have a significant increase in both residual hemoglobin $(P<0.025)$ and nonhemoglobin protein content $(P<0.01)$. Phase microscopic exam did not reveal intracellular precipitates or Heinz bodies; and thus the increased hemoglobin appeared to be associated with the membrane, as is the case when increased residual hemoglobin is found in ghosts prepared at low $\mathrm{pH}$ (35). After incubation with adenosine both hemoglobin and nonhemoglobin protein content per cell decrease, but the mean values after adenosine continue to be higher than those for ghosts prepared from fresh cells $(P<0.05$ for both nonhemoglobin protein and hemoglobin).

Initial gassing with nitrogen, followed by incubation in a sealed vessel to exclude oxygen to minimize oxidative denaturation of hemoglobin, did not prevent the changes in the properties of depleted cells. Similarly, no protection was offered by initial treatment of the cells with $0.035 \mathrm{M} \mathrm{K} \mathrm{K}_{3} \mathrm{Fe}(\mathrm{CN})_{3}$ and $0.025 \mathrm{M} \mathrm{NaCN}$ to produce cyanmethemoglobin. These results suggest that oxidative denaturation of intracellular hemoglobin does not appear to contribute to the increased rigidity of ATPdepleted cells.

Two experiments done to evaluate whether the changes in membrane properties could be accounted for by hemoglobin which had become associated with the membrane are illustrated in Table IV. The increased rigidity of hemoglobin-free ghosts produced by addition of calcium and the persistent rigidity of depleted ghosts, even though washed to remove residual hemoglobin, indicate

TABLE VII

Ghost Protein per Cell*

\begin{tabular}{lcr}
\hline & Non-Hb protein & \multicolumn{1}{c}{ Hb } \\
\hline Fresh & $5.1 \pm 0.6$ & $6.2 \pm 0.1$ \\
24-hr depleted & $8.1 \pm 1.5$ & $12.9 \pm 0.3$ \\
$\begin{array}{l}\text { 24-hr depleted }+2 \mathrm{hr} \\
\text { with 30 mM adenosine }\end{array}$ & $7.1 \pm 1.3$ & $9.4 \pm 1.3$ \\
\hline
\end{tabular}

${ }^{*} \mathrm{~g} \times 10^{-13} \pm \operatorname{SE}(\mathrm{n}=15)$. that although hemoglobin may contribute, it cannot account for the major decreases in membrane deformability.

\section{DISCUSSION}

The increasing viscosity of metabolically depleted cells described by Teitel, Nicolau, Marcu, and Xenokis (36, 37) and demonstrated in the present studies along with the decreases in membrane deformability indicate clearly that ATP depletion is associated with decreased deformability of the red cell. It also seems clear that regeneration of cellular ATP levels is associated with reversal of the decrease in cellular deformability toward preincubation levels.

Changes in surface charge density, state of the hemoglobin, cell shape, and intrinsic membrane deformability are all potential contributors to the alterations in deformability reflected by the increased viscosity and decreased filterability. However, the electrophoretic data in Table VI would appear to eliminate surface charge as a significant factor. As Meiselmann et al. (33) have indicated, in the absence of other change, increasing red cell volume may decrease blood viscosity, while a decrease in cell volume below normal will increase viscosity, possibly related to the mean corpuscular hemoglobin concentration as suggested by Erslev and Atwater (38). Fig. 6 illustrates that during the course of metabolic depletion of the incubated cells, initial decrease in membrane deformability is followed by an increase in cell volume. The latter may mask early changes in intrinsic cellular viscosity, as well as contribute to early decrease in filterability. By $28 \mathrm{hr}$, however, when the lowest shear rate viscosity has increased to $>600 \%$ of the zero time value and filterability time increased to $\infty$, cell volume had decreased again to approximately $110 \%$ of initial volume.

With regard to the contribution of hemoglobin, Ponder (2) demonstrated that normal rat hemoglobin can become paracrystalline under circumstances of cold storage. The observations of Harris, Brewster, Ham, and Castle (39), Dintenfass (40), Murphy (41), and Charache et al. (42) all indicate that pathologic hemoglobins, such as sickle hemoglobin, which are capable of undergoing transformation from a sol to a gel, or even paracrystalline or crystalline states within the cell can have a profound influence on cellular and therefore blood viscosity. Intracellular precipitation of hemoglobin, as Heinz bodies secondary to oxidative denaturation of hemoglobin (43-45), undoubtedly will contribute to cellular rigidity. Jandl, Engle, and Allen (46) have shown that such oxidative changes will occur in vitro but only after 4-5 days of incubation. Although Teitel et al. (37) have shown that sodium nitrite plus cyanide partially prevent the decrease in filterability which follows 
incubation with $\mathrm{NaF}$, presumably through production of cyanmethemoglobin, the present experiments with $\mathrm{N}_{2}$ and production of cyanmethemoglobin appear to exclude oxidative denaturation and precipitation as mechanisms. Pre- and postdepletion viscosity of hemoglobin freed of membrane protein showed no change, and Fig. 1 indicates that even at $26 \mathrm{~g} / 100 \mathrm{ml}$, hemoglobin from depleted cells show no dependence of viscosity on shear rate and no yield stress. These observations, however, do not exclude the possibilities that some of the hemoglobin, lost from the supernatant after high-speed centrifugation of the hemolysate, had undergone gelation or reversible denaturation changes predisposing to interaction with the membrane at intracellular concentrations $>$ $30 \mathrm{~g} / 100 \mathrm{ml}$. In fact, as seen in Fig. 3, the definite difference between the viscosity of ghosts prepared from fresh and depleted cells and the significant increase in hemoglobin and nonhemoglobin protein content of ghosts prepared from depleted erythrocytes appears to indicate that both hemoglobin and nonhemoglobin protein, which are soluble within metabolically intact cells, may become insoluble in the face of ATP depletion and calcium accumulation. The striking shear dependence and yield stress of the reversible viscosity changes after metabolic depletion are consistent with sol-gel changes in hemoglobin or nonhemoglobin protein. The experiments demonstrating persistent decreased deformability of ghosts from depleted cells washed to become hemoglobin-free as well as the calcium effects on white ghosts from fresh cells clearly indicate that although hemoglobin interaction with the membrane may contribute to their rigidity, changes in hemoglobin alone cannot provide the entire explanation.

The marked deformability and minimal modulus of elasticity, or maximal elastic compliance of the normal red cell membrane as characterized by Rand and Burton $(25,26)$, make clear the advantage of the biconcave discoid shape to the red cell (13). The ratio of critical hemolytic volume or effective surface area to cell volume determines both in vitro osmotic fragility and incubation hemolysis (1). Also as pointed out by Burton (14) and Gregerson et al. (22-24), the surface area: volume ratio places a critical limitation within the microcirculation on minimal pore size through which red cells can pass. The $24-$ to 28 -hr cells in the present experiments had become crenated spheres at near normal volume. However, this time interval was chosen because minimal loss of membrane lipid from normal red cells occurs at this time (5). Therefore, since little loss of membrane surface material occurs, the spherical shape and some decrease in critical hemolytic volume (1) are indicative of a configurational rearrangement of the surface, such as by folding of membrane into pits between tips of crenations. A decrease in the ratio of effective surface area: volume may, therefore, contribute to the decreased filterability and increased viscosity of cells which have undergone the disc-sphere transformation as a consequence of metabolic depletion, an observation first documented by $\mathrm{Na}$ Kao (3). In terms of shape alone, however, alteration of either a rigid or nonrigid and anisodiametric particle or molecule to a spherical configuration of equal volume actually should result in a reduced viscosity (47).

However, demonstration of a decrease in membrane deformability at $5 \mathrm{hr}$, before shape changes have occurred, (Table III) indicates that apart from shape change, there are significant alterations in intrinsic membrane deformability which will contribute to decreased filterability and increased viscosity. Therefore, although the shape factor may indeed be an important determinant of passage through the microcirculation, the decreased deformability of ATP-depleted cells before shape change, significant swelling, or lipid loss suggests that the parameter of intrinsic membrane deformability is the most sensitive indicator and perhaps the most critical consequence of decreased cellular ATP. Such partially depleted cells may be unable to pass through restricted areas of the microcirculation such as are found in the spleen, where a $3 \mu$ opening in the basement membrane separates the cords from the sinuses (48).

Garby and deVerdier (49) have recently shown that deoxygenation and lowering of $\mathrm{pH}$ result in significant reversible binding of ATP to hemoglobin with consequent decrease in phosphorylation of glucose. The increased negative pressure required to deform intact red cells in a medium of $\mathrm{pH} 6.25$ in comparison to values at $\mathrm{pH} 7.4$ suggest that a similar mechanism may operate at the lower $\mathrm{pH}$ of the splenic pulp and contribute to the changes in red cell physical properties which occur at decreased $\mathrm{pH}$ (41). Thus, $\mathrm{pH}$ effects in the splenic pulp may alter red cell deformability indirectly through lowering effective intracellular ATP levels and directly through enhancing the sol $\rightarrow$ gel transformation reflected in hemoglobin and nonhemoglobin content of ghosts prepared by Dodge, Mitchell, and Hanshan (35) at lower $\mathrm{pH}$.

The capacity of internally incorporated calcium to render the ghost membranes exceedingly stiff contrasts to magnesium which appears able to restore this parameter to nearly normal levels. Such an array of results is interpretable in a model which postulates that calcium reacts with soluble intracellular protein to make the latter insoluble and associated with the membrane. In such a system internal ATP and magnesium have an ameliorating effect by chelation or competition with calcium respectively, with resultant reversal of calcium interaction with membrane protein and (or) hemoglobin. 
Thus, although calcium accumulation by depleted cells implies the adverse interaction with the membrane, regeneration or incorporation of ATP and incorporation of magnesium may initially improve deformability by causing an internal redistribution of membrane calcium independent of total cellular calcium, providing sufficient ATP and (or) magnesium are present. The early $(6 \mathrm{hr})$ decrease in deformability, before net increase in cell calcium, is consistent with this mechanism as is the restoration of deformability which accompanies ATP regeneration at $28 \mathrm{hr}$ in spite of incomplete but significant $(P<0.01)$ reversal in total cell calcium content.

The accumulation of calcium, which is partially reversible up to $28 \mathrm{hr}$, appears important for the increasing cellular rigidity. Manery (50) has recently reviewed several examples of the role of calcium as a "membrane-hardening" agent. Other similar observations include the early studies of Heilbrunn on protoplasmic viscosity in a variety of cell types $(51,52)$ in which calcium accumulation, particularly at sites of injury, produced a "surface precipitation reaction" with resultant marked increase in viscosity. Conceivably, correlation of reversible calcium accumulation with viscosity changes reflects the state of activity of the ATP-dependent erythrocyte calcium pump proposed by Schatzmann (53). In addition, the ATP and EDTA protection of reconstituted ghosts against calcium introduction indicates that intracellular ATP acts to chelate the small amount of free intracellular calcium.

It is suggested that the following sequence of events occurs with metabolic depletion: initial early decrease in membrane deformability followed by minimal cellular swelling with decrease in filterability but little change in viscosity as ATP levels fall down to $15 \%$. Subsequently, with further depletion, a reversible ATP-dependent solgel transformation occurs at the membrane interior interface. Dintenfass (54) has suggested that changes at such an interface may contribute to cellular viscosity. Subcortical sol-gel transformation may lead to a degree of structural organization which decreases membrane deformability and dictates the disc-sphere transformation as well as increasing viscosity and decreasing filterability of the depleted cell. In addition, both the shape change and the marked increase in yield stress may be a reflection of the establishment of a three-dimensional molecular (gel) network not previously present beneath the cell surface. For example, in reference to Fig. 1, fresh red cells at an hematocrit of $80 \%$ show a yield stress of approximately 0.09 dynes $/ \mathrm{cm}^{2}$ and approximate linearity on the Casson plot, whereas the same cells after $24 \mathrm{hr}$ show a yield stress of the order of 1.2 dynes/ $\mathrm{cm}^{2}$ (more than 12-fold greater) and a marked curvature on a Casson plot. The non-Newtonian characteris-

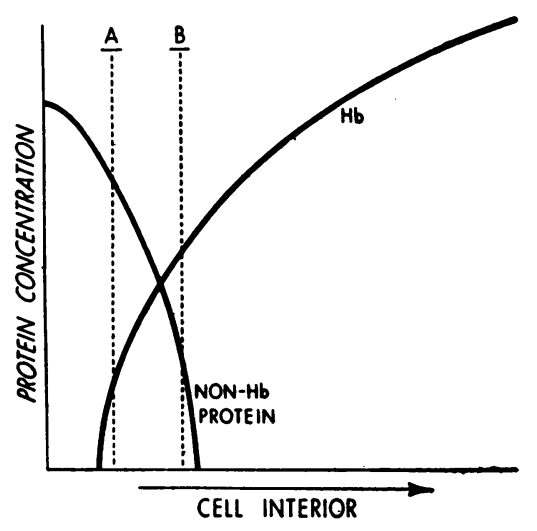

FIGURE 8 Red blood cell membrane model. In this modification of Ponder's diagram (64), the protein composition of ghosts prepared from fresh cells, with normal ATP content, is represented to the left of line $A$. The hemoglobin and nonhemoglobin protein content of ghosts prepared from ATP-depleted cells is represented to the left of line $B$.

tics of the increased viscosity may reflect the thixotropic nature of the gel structure. Although at variance with more recent textbook diagramatic representations of membrane structure, Fig. 8 is a modification of Ponder's hypothetical representation of the red cell membrane (55) which emphasizes an overlapping interface between nonhemoglobin membrane protein and hemoglobin, with the latter extending from a region of low concentration near the membrane surface to the soluble high concentration, known to be present in the interior of the cell. The present evidence suggests a model in which lines $A$ and $B$ in Fig. 8, representing the margins between soluble interior and insoluble "membrane" in fresh and depleted cells respectively, can be superimposed upon Ponder's diagram.

Although the isolation of actomysin-like proteins from erythrocyte membranes reported by Ohnishi (56) has not yet been widely confirmed by others, the evidence of calcium-stimulated ATPase activity in the membrane $(9,57,58)$, the ATP-dependent shape changes in cells and ghosts described by Nakao $(3,4)$, the calcium-ATPdependent "contraction" of ghosts recently described by Wins and Schoffeniels (59), and the demonstration by Marchesi, Palade, and Steers $(60,61)$ of filaments on the inner aspect of the membrane which resemble actin by electron microscopy all lend support to the existence of contractile proteins in the red cell membrane. Actomyosin-like material, present in insoluble form in the membrane and in a metastable state at the interface between membrane and cell interior and soluble in the presence of intracellular ATP, would appear to satisfy the requirement for a protein that would undergo an ATP-calcium-dependent sol-gel transformation. 


\section{ACKNOWLEDGMENTS}

This work was supported by U. S. Public Health Service Research Grants HE-06241-07 (Dr. Weed) and HE-06423-06 (Dr. Merrill), U. S. Public Health Service Training Grant AM-1004-03, and the U. S. Atomic Energy Project at the University of Rochester and has been assigned publication No. UR-49-923.

\section{REFERENCES}

1. Weed, R. I., and A. J. Bowdler. 1966. Metabolic dependence of the critical hemolytic volume of human erythrocytes: relationship to osmotic fragility and autohemolysis in hereditary spherocytosis and normal red cells. J. Clin. Invest. 45: 1137.

2. Ponder, E. 1955. Red cell structure and its breakdown. In Protoplasmatologia. Springer-Verlag, Vienna. 10.

3. Nakao, M., T. Nakao, S. Yamazoe, and H. Yoshikawa. 1961. Adenosine triphosphate and shape of erythrocytes. J. Biochem. 45 : 487.

4. Nakao, M., T. Nakao, and S. Yamazoe. 1960. Adenosine triphosphate and maintenance of shape of the human red cells. Nature (London). 187: 945.

5. Reed, C. F., and S. N. Swisher. 1966. Erythrocyte lipid loss in hereditary spherocytosis. J. Clin. Invest. 45: 777.

6. Weed, R. I., and C. F. Reed. 1966. Membrane alterations leading to red cell destruction. Amer. J. Med. 41: 681 .

7. Haradin, A. R., R. I. Weed, and C. F. Reed. 1967. Changes in physical properties of stored erythrocytes: relation to in vivo survival. Blood. 30: 876. (Abstr.)

8. Crosby, W. H., J. I. Munn, and F. W. Furth. 1954. Standardizing a method for clinical hemoglobinometry. U. S. Armed Forces Med. J. 5: 693.

9. Weed, R. I., C. F. Reed, and G. Berg. 1963. Is hemoglobin an essential structural component of human erythrocyte membranes? J. Clin. Invest. 42: 581.

10. Aledort, L. M., R. I. Weed, and S. B. Troup. 1966. Ionic effects on firefly bioluminescence assay of red blood cell ATP. Anal. Biochem. 17: 268.

11. Gibinson, P. J., C. R. Dauwalter, and E. W. Merrill. 1963. A rotational viscometer. Trans. Soc. Rheol. 7: 319.

12. Merrill, E. W., W. G. Margetts, G. R. Cokelet, and E. R. Gilliland. 1965. Effects of plasma proteins on the rheology of blood. Proceedings of the 4th International Congress of Rheology. A. L. Copley, editor. Interscience Publishers, Inc., New York. 135.

13. Burton, A. C. 1965. Physiology and Biophysics of the Circulation. Year Book Medical Publishers, Inc., Chicago. 52.

14. Burton, A. C. 1966. Role of geometry, or size and shape, in the microcirculation. Fed. Proc. 25: 1753.

15. Rega, A. F., R. I. Weed, C. F. Reed, G. Berg, and A. Rothstein. 1967. Changes in the properties of human erythrocyte membrane protein after solubilization by butanol extraction. Biochem. Biophys. Acta. 147: 297.

16. Teitel, A., and I. Rodulesco. 1952. O metoda de determinaire a plasticitatii globulelor rosii. Med. Interna (Bucharest). 5: 32.

17. Nicolau, C. T., P. Teitel, and M. Fotino. 1959. Loss of filterability of erythrocytes coated with incomplete antibodies. Nature (London). 184: 1808.

18. Teitel, P. 1961. Contributii la studiul hemolizei normale si pathologice. Doctoral dissertation. Stiinte Medicale, Postdoctoral Medical School, Bucharest, Rumania.
19. Teitel, P. 1967. Le test de la filtrabilite erythrocytaire (TFE) une méthode simple d'etude de certaines propriétés microheologique des globules rouges. Nouv. Rev. Fr. Hematol. 7 : 195.

20. Jandl, J. H., R. L. Simmons, and W. B. Castle. 1961. Red cell filtration in the pathogenesis of certain hemolytic anemias. Blood. 28: 133.

21. Cahn, K. D. 1967. Detergents in membrane filters. Science. 155: 195.

22. Gregersen, M. I., C. A. Bryant, W. E. Mannerle, S. Usami, and S. Chien. 1967. Flow characteristics of human erythrocytes through polycarbonate sieve. Science. $157: 827$.

23. Chien, S., S. Usami, R. J. Dellenback, and M. I. Gregersen. 1967. Blood viscosity: influence of erythrocyte deformation. Science. $157: 827$.

24. Chien, S., S. Usami, R. J. Dellenback, M. I. Gregersen, L. B. Nanninga, and M. M. Guest. 1967. Blood viscosity: influence of erythrocyte aggregation. Science. 157: 829.

25. Rand, R. P., and A. C. Burton. 1963. Mechanical properties of the red cell membrane. I. Membrane stiffness and intracellular pressure. Biophys. J. 4: 115 .

26. Rand, R. P. 1964. Mechanical properties of the red cell membrane. II. Viscoelastic breakdown of the membrane. Biophys. J. 4: 303.

27. Mitchison, J. M., and M. M. Swann. 1954. The mechanical properties of the cell surface. I. The cell elastimeter. J. Exp. Biol. 31 : 443.

28. Fuhrmann, G. F., and G. Ruhenstroth-Bauer. 1965. Cell electrophoresis employing a rectangular measuring cuvette. In Cell Electrophoresis. E. J. Ambrose, editor. Little, Brown and Company, Boston. 22.

29. Bing, F. C., and R. W. Baker. 1931. The determination of hemoglobin in minute amounts of blood by Wu's method. J. Biol. Chem. 92: 589.

30. Dacie, J. V. 1956. Practical Haematology. J. London and A. Churchill, editors. 2nd edition. 140.

31. Lowry, O. H., N. J. Rosebrough, L. Farr, and R. J. Randall. 1951. Protein measurement with Folin phenol measurement. J. Biol. Chem. 193: 265.

32. Hoffman, J. F. 1962. The active transport of sodium by ghosts of human red blood cells. J. Gen. Physiol. 45: 837.

33. Meiselman, H.' J., E. W. Merrill, E. R. Gilliland, G. A. Pelletier, and E. W. Salzman. 1967. Influence of total plasma osmolarity on the rheology of human blood. $J$. Appl. Physiol. 22: 772.

34. Nakao, K., T. Wada, T. Kamiyani, M. Nakao, and K. Nagano. 1962. A direct relationship between adenosine triphosphate level and in vivo viability of erythrocytes. Nature (London). 194: 877.

35. Dodge, J. T., C. Mitchell, and D. J. Hanahan. 1963. The preparation and chemical characteristics of haemoglobinfree ghosts of human erythrocytes. Arch. Biochem. Biophys. 100: 119 .

36. Teitel, P., and C. T. Nicolau. 1964. Physico-chemical and metabolic factors influencing the erythrocyte rheology. Proceedings of the Symposium on Molecular Biology and Pathology, Bucharest. 59.

37. Teitel, P., I. Marcu, and A. Xenokis. 1968. Erythrocyte microrheology: its dependence on the reduced sulfhydryl groups and hemoglobin integrity. Folia Haematol. (Leipzig). $90: 281$.

38. Erslev, A. J., and J. Atwater. 1963. Effect of mean corpuscular hemoglobin concentration on viscosity. J. Lab. Clin. Med. 62: 401.

39. Harris, J. W., H. A. Brewster, T. H. Ham, and W. B. Castle. 1956. Studies on the destruction of red blood cells. 
$\mathrm{X}$. The biophysics and biology of sickle cell disease. Arch. Intern. Med. $97: 145$.

40. Dintenfass, L. 1964. Rheology of packed red blood cells containing hemoglobin A-A, S-A, S-S. J. Lab. Clin. Med. 64: 594 .

41. Murphy, J. R. 1967. The influence of $\mathrm{pH}$ and temperature on the physical properties of normal erythrocytes and erythrocytes from patients with hereditary spherocytosis. J. Lab. Clin. Med. 69: 758.

42. Charache, S., C. L. Conley, D. F. Waugh, R. J. Ugoretz, and J. Spurrell. 1967. Pathogenesis of hemolytic anemia in homozygous hemoglobin-C disease. J. Clin. Invest. 64: 1795 .

43. Harley, J. D., and A. M. Mauer. 1961. Studies on the formation of Heinz bodies. II. The nature and significance of Heinz bodies. Blood. 17: 418.

44. Allen, D. W., and J. H. Jandl. 1961. Oxidative hemolysis and precipitation of hemoglobin. II. Role of thiols in oxidant drug action. J. Clin. Invest. 40: 454.

45. Huisman, T. H. J., A. M. Dozy, B. F. Horton, and G. M. Nechtman. 1966. Studies on the heterogeneity of hemoglobin. X. The nature of various minor hemoglobin components produced in human red blood cell hemolysates on aging. J. Lab. Clin. Med. 67: 355 .

46. Jandl, J. H., L. K. Engle, and D. W. Allen. 1960. Oxidative hemolysis and precipitation of hemoglobin. I. Heinz body anemias as acceleration of red-cell aging. J. Clin. Invest. 39: 1818.

47. Merrill, E. W. 1963. Non-Newtonianism in Thin Liquids. In Modern Chemical Engineering. Reinhold Publishing Corp., New York. 141.

48. Weiss, L. 1962. The structure of fine splenic arterial vessels in relation to hemoconcentration and red cell destruction. Amer. J. Anat. 111: 131.

49. Garby, L., and C. H. deVerdier. 1968. Binding of ATP and 2,3-DPG to hemoglobin-effect on erythrocyte glycoly- sis. In Proceedings of the 1st. International Symposium on Metabolism and Membrane Permeability of Erythrocytes and Thrombocytes. E. Deutsch and E. Gerlach, editors. Verlog der Wiener Medizinischen Akademie, Vienna.

50. Manery, J. F. 1966. Effects of $\mathrm{Ca}$ ions on membranes. Fed. Proc. 25: 1804

51. Heilbrunn, L. V. 1943. An outline of general physiology. W. B. Saunders Co., Philadelphia. 2nd edition. 86.

52. Heilbrunn, L. V. 1956. The Dynamics of Living Protoplasm. Academic Press Inc., New York.

53. Schatzmann, H. J. 1966. ATP dependent $\mathrm{Ca}^{++}$extraction from human red cells. Experientia (Basal). $22: 365$.

54. Dintenfass, L. 1964. Molecular and rheological considerations of the red cell membrane in view of the internal fluidity of the red cell. Acta. Haematol. 32: 299.

55. Ponder, E. 1954. Present concepts of the structure of the mammalian red cell. Blood. 9: 227.

56. Ohnishi, T. 1962. Extraction of actin and myosin-like proteins from erythrocyte membrane. J. Biochem. (Tokyo). 52: 307.

57. Dunham, E. T., and I. M. Glynn. 1961. Adenosinetriphosphatase activity and the active movement of alkali metal ions. J. Physiol. 156: 274.

58. Wins, P., and E. Schoffeniels. 1966. Studies on red cell ghost ATPase systems: properties of a $\left(\mathrm{Mg}^{2+}\right.$ and $\left.\mathrm{Ca}^{2+}\right)$ dependent ATPase. Biochem. Biophys. Acta. 120: 341.

59. Wins, P., and E. Schoffeniels. 1966. ATP and $\mathrm{Ca}^{++}-$ linked contraction of red cell ghosts. Arch. Int. Physiol. Biochem. 74: 812.

60. Marchesi, V. T., and G. E. Palade. 1967. The localization of $\mathrm{Mg}-\mathrm{Na}-\mathrm{K}$-activated adenosine triphosphatase on red cell ghost membranes. J. Cell. Biol. 35: 385.

61. Marchesi, V. T., and E. Steers, Jr. 1968. Selective solubilization of a protein component of the red cell membrane. Science. 159: 203. 